\title{
Harmful effects of endosulfan treatment on cyanobacterial distribution and some macromolecules of soybean plant
}

\author{
Neveen Abdel-Raouf and Nadia M. El-Shafey* \\ Department of Botany, Faculty of Science, Beni-Suef University, Salah Salem St., Beni-Suef, Egypt.
}

Accepted 15 September, 2009

\begin{abstract}
In a trial to evaluate the impact of one of the commonly used insecticides in Egypt, a plot area cultivated with soybean was sprayed with endosulfan. Some of the biochemical criteria of the treated soybean and the biodiversity and biochemical activity of its companion cyanobacteria were compared with those of the untreated ones. The results revealed that endosulfan application caused inhibition in the attendance and biodiversity of the soil cyanobacteria found in the rhizosphere of the treated soybean, specially the filamentous species. The treated soil showed a highly significant inhibition in their ARA (acetylene-reducing activity) and exopolysaccharides. The biochemical analysis showed a high significant decrease in all the carbohydrate fractions as well as DNA and RNA contents of the treated soybean plants compared with the untreated ones. However, the total soluble proteins significantly Increased, indicating some defense pattern against the lethal effects of endosulfan. From the results, it could be concluded that application of endosulfan has a significant potential to change ecosystems and soil biological processes and could potentially reduce future farm productivity and cause harmful impact to agriculture.
\end{abstract}

Key words: Cyanobacteria, endosulfan, insecticide, soybean.

\section{INTRODUCTION}

Soil is a dynamic system in which the physical, chemical and biotic components are in a state of equilibrium. Application of insecticides without taking care of the other soil constituents disturbs this equilibrium which adversely affects the productivity of the soil. Pesticides reaching the soil affect non-target organisms and their activities (Tu and Miles, 1976). Pesticide contamination poses significant risks to the environment and non-target organisms ranging from beneficial soil microorganisms, to insects, plants, fishes and birds. The heavy treatment of soil with pesticides can cause populations of beneficial soil microorganisms to decline. Maintenance of the soil biota other than the harmful pests help in better crop nutrient man-

${ }^{*}$ Corresponding author. E-mail: nadia69shafey@yahoo.com. Tel: 002-0181801282. Fax: 002-082-2325045.

Abbreviation: ARA, acetylene-reducing activity. agement and maintenance of soil health while working in perfect harmony with nature. Insecticides frequently exert inhibitory or stimulatory effects on the growth or other activities of microorganisms and higher plants as well as on fauna.

Blue-green algae, especially the nitrogen-fixers cyanobacteria, represent the major microorganisms which contribute to soil fertility. These organisms play an important role in this system by providing a steady input of fixed nitrogen (Roger et al., 1986). Also, cyanobacteria have been assumed to produce growth promoting substances like hormones, vitamins, amino acids or many other components that enhances germination (Singh and Trehan, 1973; Grieco and Desrochers, 1978; Rodgers et al., 1979; Venkataraman, 1981; de Caire et al., 1997; de Mule et al., 1999; Godd et al., 1999; Omar, 2000). Most of the soil and aquatic microscopic algae are sensitive to insecticides due to the fact that algae are engaged in photosynthesis and that many insecticides interfere with this process. It is of particular interest to mention that 
algae participate actively in the binding and neutralizing of xanobiotics (Jampani, 1989; Baeza-squiban et al., 1990).

The growth of cyanobacteria creates the conditions for colonization by higher plants, since they are sources for biological change and accumulation of humus and nitrogen. They also indicate soil quality and help to protect the soil crust from erosion. In this respect, Kaushik and Murti (1981) studied the effect of cyanobacteria on physico-chemical properties of alkali soils. They found that application of cyanobacteria resulted in significant improvement in the aggregation status of soil and brought down appreciably the $\mathrm{pH}$, electric conductivity and exchangeable sodium; furthermore, they increased considerably the hydraulic conductivity of soil.

Most studies on the effect of pesticides on plant and soil microbial activity have been laboratory studies. The assessment of the effect of insecticide application on the plant growth and the companion soil cyanobacteria has so far received little attention. The present field study was undertaken to qualify the effect of application of one of the commonly used insecticide ( $\alpha$-endosulfan) on soybean plants and the biodiversity and biochemical activity of soil cyanobacteria.

\section{MATERIALS AND METHODS}

\section{The plot area and the used insecticide}

A plot area of about $300 \mathrm{~m}^{2}$ was used for this study. The area was cultivated with soybean. Half of the area was kept without treating (control). The other one was sprayed with the investigated insecticide. The used insecticide with its chemical name a-endosulfan (Chemical formula $\mathrm{C}_{9} \mathrm{H}_{6} \mathrm{Cl}_{6} \mathrm{O}_{3} \mathrm{~S}$ ) was applied by spraying at the recommended dose $\left(600 \mathrm{ml}\right.$ of endosulfan added to $150 \mathrm{I} \mathrm{H}_{2} \mathrm{O}$ feddan $^{-1}$ ).

\section{Isolation and culturing of cyanobacteria}

Soil samples were taken by cores $(5 \mathrm{~cm}$ diameter) from subsurface soil up to $5 \mathrm{~cm}$ around the roots of soybean plants seeded in control area (untreated). The other soil samples were taken at the same time and at similar depth around the soybean plants seeded in treated lands with $\alpha$-Endosulfan after 3 days of application. Cores of all materials were placed in pre-sterilized plastic bags and returned to the laboratory, where $2.5 \mathrm{~g}$ aliquot of each wet sample was subsequently blended in $20 \mathrm{ml}$ dist. $\mathrm{H}_{2} \mathrm{O}$ for identification of the live cells. For the cyanobacterial culturing, a method recommended by Jurgensen and Davey (1968) was applied. One gram of each soil sample was placed in $99 \mathrm{ml}$ of sterile water and then placed in a shaker for $15 \mathrm{~min}$. Five replicate Petri-dishes were inoculated each with $1 \mathrm{ml}$ of the appropriate dilution and $25 \mathrm{ml}$ of nutrient agar medium $\left(45^{\circ} \mathrm{C}\right)$ were added. Myers' $\mathrm{C}$ medium incubated at $35 \pm$ $1^{\circ} \mathrm{C}$ was used for isolation of blue-green algae. For nitrogen-fixing species Allen's free-nitrogen media (Allen and Stanier, 1968) was applied. All were inoculated on a 16 / 8 h light / dark cycle with a light intensity of 3500 to 4500 Lux. The cyanobacterial taxa were identified according to Desikachary (1959).

\section{Soil analysis}

The acetylene-reducing activity (ARA) was assayed by acetylene reduction technique according to Hardy et al. (1973). ARA was expressed as Umol h-1 $\mathrm{kg}^{-1}$ dry soil. The method adopted by Lowe (1993) was used for determination of exopolysaccharides. The soil exopolysaccharides was recorded as $\mathrm{mg}$ glucose $/ \mathrm{kg}$ soil.

\section{Plant analysis}

Some of the plant materials were oven dried at $80^{\circ} \mathrm{C}$ until constant weight and used for sugar determination, while the fresh material was kept for determination of soluble protein and nucleic acids. Total soluble proteins were determined quantitatively according to the method described by Bradford (1976) and expressed as $\mathrm{mg} \mathrm{g}^{-1}$ fresh wt. The extraction of nucleic acids was carried out by the method cited by Mohamed and El-Sayed (1982). Diphenylamine test outlined by Clark and Switzer (1977) was used to estimate the DNA content. RNA was assayed by orcinol test as mentioned by Clark and Switzer (1977). DNA and RNA were calculated as $\mathrm{mg} \mathrm{g}^{-1}$ fresh wt.

The soluble sugars were extracted from the dried plant material according to the method presented by Upmeyer and Koller (1973). One $\mathrm{ml}$ of soluble sugar extract was heated with $1 \mathrm{ml} 6 \mathrm{~N} \mathrm{HCl}$ for 12 $\min$ at $70^{\circ} \mathrm{C}$ in water bath to hydrolyze the non-reducing sugars (Gaines, 1973). The method of Streeter and Jeffers (1979) was used to hydrolyze the insoluble carbohydrate. Nelson's test was used to determine the reducing value of each sugar extract as glucose (Clark and Switzer, 1977). All carbohydrate factors were expressed as mg glucose $\mathrm{g}^{-1}$ dry wt.

\section{Statistical analysis}

Analysis of variance (one-way ANOVA) was employed to determine if treatments were significantly different at the levels of 5 and $1 \%$ (Zar, 1984). All experiment was repeated for three replicates.

\section{RESULTS AND DISCUSSION}

The assessment of the toxic effect of endosulfan on the quantity and distribution of nitrogen-fixing cyanobacteria (Table 1) indicates a progressive inhibition in the biodiversity and the attendance of recorded cyanobacteria, especially the filamentous species compared to the control. These inhibitory effects may be attributed to the lethal effects of endosulfan on the growth and nitrogen fixing capacity of cyanobacteria. These results are in harmony with findings of Singh et al. (1983). They reported that the thiocarbamate benthiocarb inhibits the growth of Nostoc linckia. In addition, they recorded a reduction in heterocyst formation at all studied insecticides concentrations. Also, similar results were recorded by Shabana (1991) who found that growth and dry weight of Anabaena oryzae and Aulosira fertilssima were significantly decreased by application of Parathion pesticide.

Nitrogen fixation by cyanobacteria is an important source of nitrogen input in the nitrogen cycle of cultivated soils and could limit pollution problems by lowering the demand for chemical insecticides (Quesada et al., 1997). Acetylene-reducing activity (ARA) in treated soils (Table 2) was found to be highly significantly affected by endosulfan treatment. The obtained results indicated that endosulfan treatment could lead to significant inhibitions 
Table 1. Effect of endosulfan treatment on the distribution of nitrogen fixing cyanobacterial species.

\begin{tabular}{|c|l|c|c|}
\hline \multirow{2}{*}{ No. } & \multirow{2}{*}{ Cyanobacterial species } & \multicolumn{2}{|c|}{ Appearance } \\
\cline { 3 - 4 } & & Before treatment & After treatment \\
\hline 1 & Chroococcus minutus & ++ & + \\
2 & Gloeocapsa stegophila & +++ & ++ \\
3 & Calothrix parietina & ++ & - \\
4 & Calothrix thermalis & + & - \\
5 & Nostoc calcicola & ++ & - \\
6 & Nostoc commune & ++ & - \\
7 & Nostoc entophytum & + & - \\
8 & Nostoc minutum & + & - \\
9 & Nostoc paludosum & + & - \\
10 & Nostoc passerianum & + & - \\
11 & Nostoc punctiforme & +++ & - \\
12 & Nodularia harvenyana & ++ & + \\
13 & Anabaena ambigua & +++ & - \\
14 & Anabaena anomala & ++ & - \\
15 & Anabaena doliolum & +++ & - \\
16 & Anabaena naviculoides & +++ & - \\
17 & Oscillatoria acuta & ++ & - \\
18 & Phormidium corium & + & - \\
19 & Phormidium tenue & ++ & - \\
20 & Lungbya dendrobia & + & - \\
21 & Microcoleus acutissimus & ++ & + \\
\hline
\end{tabular}

Table 2. Effect of endosulfan treatment on the acetylene-reducing activity (ARA) and soil exopolysaccharides.

\begin{tabular}{|l|c|c|}
\hline \multicolumn{1}{|c|}{ Soil } & ARA (Umol $\mathbf{~ h}^{-\mathbf{1}} \mathbf{~ g}^{-1}$ dry soil) & Exopolysaccharides $\left(\mathbf{m g}\right.$ glucose $\mathbf{~ k g}^{-1}$ soil) \\
\hline Control & $234 \pm 1.00$ & $349.33 \pm 3.05$ \\
Treated & $49 \pm 1.00$ & $38.33 \pm 2.51$ \\
LSD at $5 \%$ & 2.27 & 6.34 \\
LSD at $1 \%$ & 3.76 & 10.52 \\
\hline
\end{tabular}

Data recorded as mean of three replicates \pm SD.

of nitrogenase activity values of inhabited cyanobacteria. In the same manner, Ibraheem (2002) and Abdel-Raouf (2003) reported that application of popular insecticides, Larvin, Sevin, Sumi-alpha and Dursban inhibited the nitrogenase activities of cyanobacteria.

The nitrogen fixation process depends mainly on the equilibrium between $\mathrm{CO}_{2}$ and $\mathrm{O}_{2}$ gases. This ratio is specific, but generally under high $\mathrm{O}_{2}$ tension, inhibition of acetylene reduction occurs (Stewart and Pearson, 1970). These ratios of $\mathrm{CO}_{2} / \mathrm{O}_{2}$ are controlled by respiration and photosynthesis processes (Lex et al., 1972). The dependence of nitrogen fixation process on photosynthesis comprises also, the carbon skeleton, ATP and hydrogen donor (Wolk, 1968). It may be suggested that the inhibition of nitrogenase-activity by endosulfan application in the tested soil, as well as, the un-stability for sometimes in the patterns of aerobic and anaerobic inhibitions, may be attributed to the effect of endosulfan on the size of the pool of reduction, which the photosynthetic products provide. It may alter the ratios between $\mathrm{CO}_{2}$ and $\mathrm{O}_{2}$ during photosynthesis and photorespiration. The rate of inhibition and its severity depends on the organisms under test and concentration of the insecticides. Kobbia and EL-Sharony (1983) reported that nitrogenase activity was inhibited in three blue-green algae by treatment with 2,4-D herbicide.

Concerning the high contents of exopolysaccharides appearing in untreated soil (Table 2), it may be attributed to the activity of inhabited cyanobacteria which is described as exopolysaccharides producing organisms and exploited in this filed (Metting et al., 1988). In this respect, Falshini et al. (1997) found that the presence of cyano- 
Table 3. Effect of endosulfan treatment on some cellular macromolecules of the shoot system of soybean.

\begin{tabular}{|c|c|c|c|c|c|c|c|c|}
\hline Plant & $\begin{array}{c}\text { Soluble } \\
\text { carbohydrates } \\
\text { (mg g }{ }^{-1} \text { dry wt.) }\end{array}$ & $\begin{array}{l}\text { Reducing } \\
\text { sugars (mg } \\
\mathrm{g}^{-1} \text { dry wt.) }\end{array}$ & $\begin{array}{l}\text { Non reducing } \\
\text { sugars (mg g } \\
\text { dry wt.) }\end{array}$ & $\begin{array}{c}\text { Insoluble } \\
\text { carbohydrates } \\
\text { ( } \mathrm{mg} \mathrm{g}^{-1} \text { dry wt.) }\end{array}$ & $\begin{array}{c}\text { Total } \\
\text { Carbohydrates } \\
\text { (mg g } \\
\text { (-1 dry wt.) }\end{array}$ & $\begin{array}{l}\text { Total soluble } \\
\text { Proteins (mg } \\
\mathrm{g}^{-1} \text { fresh wt.) }\end{array}$ & $\begin{array}{c}\text { DNA ( } \mu g^{-1} \\
\text { fresh wt.) }\end{array}$ & $\begin{array}{l}\text { RNA ( } \mu g^{-1} \\
\text { fresh wt.) }\end{array}$ \\
\hline Control & $35.34 \pm 2.08$ & $28.22 \pm 2.32$ & $7.12 \pm 0.69$ & $46.61 \pm 1.23$ & $81.96 \pm 3.03$ & $8.14 \pm 0.07$ & $1.16 \pm 0.09$ & $7.12 \pm 0.12$ \\
\hline Treated & $23.65 \pm 2.20$ & $18.80 \pm 1.45$ & $4.82 \pm 0.75$ & $31.84 \pm 2.14$ & $55.49 \pm 3.78$ & $9.43 \pm 0.67$ & $0.94 \pm 0.06$ & $4.77 \pm 0.66$ \\
\hline LSD at $5 \%$ & 4.871 & 4.35 & 1.64 & 3.96 & 7.77 & 1.07 & 0.18 & 1.07 \\
\hline LSD at $1 \%$ & 8.078 & 7.27 & 2.72 & 6.57 & 12.89 & 1.78 & 0.29 & 1.77 \\
\hline
\end{tabular}

Data recorded are the mean of three replicates $\pm S D$.

bacteria in soil increases the soil contents of exopolysaccharides resulting in the protection of the soil porosity by reducing damaging effects of water and also being of primary aggregation as a consequence of interaction between the secreted exopolysaccharides and the units of the fine soil fraction.

The results of biochemical analysis showed a high significant inhibition in the accumulation of total carbohydrates, soluble carbohydrates, reducing and non-reducing sugars of the treated soybean compared with the control ones (Table 3 ). The results also show a high significant decrease in DNA and RNA contents in response to endosulfan application (Table 3 ). The decrease in carbohydrates and carbohydrate fractions of soybean treated by endosulfan may be attributed to the interference of endosulfan in the metabolism of soybean cells. Also, this may indicate a decline in the rate of photosynthesis and suggests that the decrease in sugars could be attributed to an inhibition in the rate of their biosynthesis. In contrast, the total soluble proteins of soybean treated with endosulfan revealed significant increase in this content (Table 3), indicating some defense pattern for protection against the lethal effects of endosulfan.

Evaluating the response of soybean plants to grow, develop and flourish in such studied soil treated by endosulfan indicates the necessity of cyanobacteria to such soil samples. In this respect, Singh (1961) reported the beneficia effects of cyanobacterial inoculation on the yield of sugarcane and grass. Moreover, Kerni et al. (1981) found that cyanobacterial inoculation significantly promoted the growth of seedling of guava when compared to the control. The negative impact of endosulfan on cyanobacteria could be the indirect reason for the growth inhibition of soybean plants. This reason may comprise of one or combination of many factors. Cyanobacteria are known to secrete several different categories of secondary metabolites, such as auxin-like substances (Venkataraman, 1981), cytokinin-like substances (Rodgers et al., 1979), gibberellin-like substances (Singh and Trehan, 1973), vitamin B (Grieco and Desrochers, 1978), organic acids (Hellebust, 1974) and antibiotics (Moore, 1996; Schlegel et al., 1999). A decrease in one or more of these products in the rhizosphere may affect the growth of soybean plants. Venkataraman (1981) reported that the excretion of ascorbic acid by cyanobacteria is known and play a dual role as exudates from cyanobacteria in rice field; it can accelerate the growth and development of the plant directly and as a constituent of the cyanobacterial cell, it may participate in processes of nitrogen fixation and nitrate reduction. In this respect, Ibraheem (2007) confirmed that the cyanobacterial application as inoculum increased the protein, chlorophyll and carbohydrate contents of lettuce plants.

From present study, it could be concluded that endosulfan has the potential to change ecosystems and soil biological processes significantly and could potentially reduce future farm productivity and cause harmful impact to agriculture. There is an urgent need to reduce insecticide contamination in our environment by using safer, nonchemical insect control methods. This work also confirms that soil cyanobacteria will serve as good indicators of pollution due to their sensitivity to synthetic pollutants.

\section{REFERENCES}

Abdel-Raouf $N$ (2003). Toxicity of sumi-alpha and dursban insecticides on the growth viability, metabolism and nitrogen fixing capacity of two Nostoc species. Egypt. J. Phycol. 4: 113-130.

Allen MM, Stanier RY (1968). Growth and division of some unicellular blue-green algae. J. Gen. Microbiol. 51:199-202. Baeza-squiban A, Bouaicha N, Santa-Maria A, Marano $F$ (1990). Demonstration of the excretion by Dunaliella bioculata of esterases implicated in the metabolism of deltamethrin, a pyrethroid insecticide. Bull. Environ. Contam. 45: 39-45.

Bradford MM (1976). A rapid and sensitive method for the quantitation of microgram quantities of protein utilizing the principle of protein-dye binding. Anal. Biochem. 72:248-254 
Clark JM, Switzer RL (1977). Experimental Biochemistry, 2nd Edn., Freedman and Company, San Francisco.

de Caire GZ, de Cano MS, de Mule MCZ, Palma RM, Colombo K (1997). Exopolysaccharide of Nostoc muscorum (cyanobacteria) in the aggregation of soil particles. J. Appl. Phycol. 9: 249-253.

de Mule MCZ, de Caire GZ, de Cano MS, Palma RM, Colombo K (1999). Effect of cyanobacterial inoculation and fertilizers on rice seedings and post harvest soil structure. Commun. Soil Sci. Plant Anal. 30: 97-107.

Desikachary TV (1959). Cyanophyta. PhD dissertation, Univ. of Madras, New Delhi.

Falshini L, Sparvoli E, Tomaselli L (1997). Effect of Nostoc (Cyanobacteria) inoculation on soil structure and stability of clay soils. Biol. Fert. Soil, 23: 346-352.

Gaines TP (1973). Automated determination of reducing sugars, total sugars and starch in plant tissue from one weighted sample. J. Assoc. Anal. Chem. 56: 1419-1424.

Godd GA, Bell SG, Kaya K, Ward CJ, Beattie KA, Metcalf JS (1999). Cyanobacterial toxins, exposure routes and human health. Eur. J. Phycol. 34: 405-415.

Grieco E, Desrochers R (1978). Production de vitamine B12 par une algae blue. Can. J. Microbiol. 24: 1562-1566.

Hardy RWF, Burns RC, Holsten RD (1973). Application of acetyleneethylene assay for measurement of nitrogen fixation. Soil Biol. Biochem. 5: 47-81.

Hellebust JA (1974). Extracellular products. In: Stewart WDP (ed) Algal Physiology and Biochemistry, Vol. 10, Botanical Monographs Berkeley, CA. pp. 838-865.

Ibraheem IBM (2007). Cyanobacteria as alternative biological conditioners for bioremediation of barren soil. Egypt. J. Phycol. 8: 99117.

Ibraheem IBM (2002). Hazard application of two common insecticides (Larvin and Sevin) on the growth, metabolic activity and nitrogen fixing capacity of cyanobacteria. Egypt. J. Phycol. 3: 103-115.

Jampani CSR (1989). Detoxification of pesticides dimethoate and thiometon by green alga. Environ. Ecol. 7: 504-505.

Jurgensen MF, Davey CB (1968). Nitrogen fixating blue-green algae in acid forest and nursery soils. Can. J. Microbiol. 14: 1179.

Kaushik BD, Murti KG (1981). Effect of blue-green algae and gypsum application on physico-chemical properties of alkali soils. Phykos. 20: 91-94.

Kerni PN, Shant PS, Sapru BI (1981). Effect of nitrogen fixing bluegreen algae on Guava seedlings (Psidium gaujava. L.). Phykos. 20:95-98.

Kobbia IA, El-Sharouny HM (1983). The effect of 2, 4-D on nitrogen fixing capacity of some blue-green algae. Egyptian Society of Applied Microbiology Proc. V Conf. Microbiol. Cairo, May 1983. Vol. II-Soils \& Water Microbiol. Paper No. 50.

Lex M, Silvester WB, Stewart WDP (1972). Photorespiration and nitrogenase activities in the blue green alga Anabaena cylindrical. Proc. Roy. Soc. B. 180: 87-102.

Lowe LE (1993). Total and labile polysaccharide analysis. Can. Soc. Soil Sci. p. 342
Metting B, Rayburn WR, Renaud PA (1988). Algae and agriculture, In Lembi C.A, Waalaud RA (eds) Algae and human affairs, Cambridge University Press, Cambridge, UK, pp. 335-370.

Mohamed YAH, El-Sayed MA (1982). The role of cobalt in nucleic acid content of Azotobacter chroocaccum. Iraqi J. Sci. 23: 421-424.

Moore RE (1996). Cyclic peptides and depsipeptides from Cyanobacteria: a review. J. Ind. Microbiol. 16: 134-143.

Omar Hanan H (2000). Nitrogen-fixing abilities of some cyanobacteria in sandy loam soil and exudate efficiency on Rice grain germination. Egypt. J. Phycol. 1: 157-167.

Quesada A, Leganes F, Fernandezy-aleiente E (1997). Environmental factors controlling N2-fixation in Mediterranean rice fields. Microbiol. Ecol. 34: 39-48.

Rodgers GA, Bergman B, Henriksson E, Urdis M (1979). Utilization of blue-green as biofertilizers. Plant Soil, 52: 99-107.

Roger PA, Ardales TS, Watanabe I (1986). Chemical composition of cultures and natural samples of $\mathrm{N} 2$-fixing blue-green algae from rice fields. Biol. Fertil. Soils Z: 131-146.

Schlegel I, Doan NT, de Chazal N, Smith GD (1999). Antibiotic activity of new cyanobacterial isolates from Australia and Asia against green algae and Cyanobacteria. J. Appl. Phycol. 10: 471-479.

Shabana-Effat F (1991). Phosphatase activity and phosphorus metabolism in some selected cyanobacteria as affected by Parathion. Bull. Fac. Sci. Cairo Univ. 59: 117-128.

Singh RK, Singh BD, Singh HN (1983). Inhibition of photosystem II of nitrogen-fixing blue-green alga Nostoc linckia by the rice-field herbicide benthiocarb. Z. Allg. Mikrobiol. 23: 435-441.

Singh RN (1961). Role of blue-green algae in nitrogen economy of India. Indian Council Agric. Res., New Delhi, Indian.

Singh VP, Trehan T (1973). Effects of extracellular products of Aulosira fertilissuna on the growth of rice seedlings. Plant Soil, 38: 457-464.

Stewart WDP, Pearson HW (1970). Effect of aerobic and anaerobic condition on growth and metabolism of blue-green algae. Proc. Roy. Soc. Lond. B. 175: 293-311.

Streeter JG, Jeffers DL (1979). Distribution of total non-structural carbohydrates in soybean plants having increased reproductive load. Crop Sci. 19: 729-734.

Tu CM, Miles JRW (1976). Interactions between insecticides and soil microbes. Res. Rev. 64: 17-65.

Upmeyer DJ, Koller HR (1973). Diurnal trends in net photosynthetic rate and carbohydrate levels of soybean leaves. Plant Physiol. 51: 871 874.

Venkataraman GS (1981). Blue-green algae for rice production- a manual for its promotion. FAO Soils Bull. 64: 24 .

Wolk CP (1968). Movement of carbon from vegitative cells to heterocysts in Anabaena cylindrica. J. Bact. 96:2138-2143.

Zar JH (1984). Biostatistical analysis. 2nd ed. Prentice. Hall, Englewood Cliffs, NJ, USA. 